\title{
浅谈重点行业企业用地调查信息采集地块空间分布一一江苏 某县为例分析
}

李云燕

南京大学环境规划设计研究院股份公司

DOI:10.32629/eep.v3i7.908

\begin{abstract}
[摘 要] 本文以江苏某县级市重点行业企业用地调查信息采集工作为例分析说明该县涉及企业的空间 分布,研究地块位置、关注度、行业、规模、重点目标等存在的关系,能够摸清该区域内污染地块状况, 为进一步掌握污染地块环境风险数据打下基础。
\end{abstract}

[关键词] 重点行业企业用地调查; 信息采集；空间分布

中图分类号：X321 文献标识码：A

土壤是经济社会可持续发展的物 质基础, 关系人民群众身体健康, 关系 美丽中国建设, 保护好土壤环境是推进 生态文明建设和维护国家生态安全的 重要内容。

土壤污染具有隐蔽性、滞后性、累 积性和地域性、不均匀性、难可逆性等 特点, 污染物在土壤中更难迁移、扩散 和稀释 ${ }^{[1]}$ 。土壤污染一旦发生, 仅仅依 靠切断污染源的方法很难恢复基于土壤 现状 ${ }^{[2]}$ 。为打好土壤污染防治攻坚战, 摸 清土壤污染状况 “家底”, 自2018年以来, 国家及省市各级环保部门开展了重点行 业企业用地土壤污染状况调查工作, 为后 续土壤污染治理及保护提供基础数据 ${ }^{[3]}$ 。

本次以笔者参与的江苏某县级市重 点行业企业用地调查信息采集工作为例 分析说明该县涉及企业的空间分布。

\section{1 区域概况}

本次调查区域为江苏苏北一县级市, 全县地势平坦低洼, 地处北亚热带、属于 季风气候。近年来, 全县大力提升改造化 工、花炮、纺织、铸造等传统产业, 强制 淘汰重污染行业落后产能, 逐步搬迁改 造或关停并转移环境敏感区内的高风险 企业。自2010年以来, 该县关闭了一批重 污染化工生产企业, 淘汰了一批小纺织、 小铸造、小印染和小电镀企业。
表 1 江苏某县信息采集地块关注度分布表

\begin{tabular}{|c|c|c|c|c|}
\hline 序号 & 地块关注度 & 企业状态 & 数量 $($ 个) & 占比 $(\%)$ \\
\hline 1 & 高风险 & 1 & 0 & 0 \\
\hline 2 & \multirow{2}{*}{ 中关注度 } & 在产 & 25 & \multirow{2}{*}{$53(73 \%)$} \\
\hline 3 & & 关闭 & 28 & \\
\hline 4 & \multirow{2}{*}{ 低关注度 } & 在产 & 10 & \multirow{2}{*}{$20(27 \%)$} \\
\hline 5 & & 关闭 & 10 & \\
\hline 6 & 合计 & / & 1 & 73 \\
\hline
\end{tabular}

表 2 江苏某县信息采集地块行业分布

\begin{tabular}{|c|c|c|c|c|c|c|c|}
\hline $\begin{array}{l}\text { 序 } \\
\text { 号 }\end{array}$ & 行业类别及代码 & $\begin{array}{l}\text { 数量 } \\
(\text { 个) }\end{array}$ & $\begin{array}{l}\text { 占比 } \\
(\%)\end{array}$ & $\begin{array}{l}\text { 序 } \\
\text { 号 }\end{array}$ & 行业类别及代码 & $\begin{array}{l}\text { 数量 } \\
(\text { 个) }\end{array}$ & $\begin{array}{l}\text { 占比 } \\
(\%)\end{array}$ \\
\hline 1 & 14 食品制造业 & 1 & 1.4 & 2 & 17 纺织业 & 2 & 2.7 \\
\hline 3 & $\begin{array}{c}19 \text { 皮革、毛皮、羽毛及其制 } \\
\text { 品和制鞋业 }\end{array}$ & 1 & 1. 4 & 4 & 22 造纸和纸制品业 & 1 & 1.4 \\
\hline 5 & $\begin{array}{c}25 \text { 石油加工、炼焦和核燃料 } \\
\text { 加工业 }\end{array}$ & 1 & 1. 4 & 6 & $\begin{array}{c}26 \text { 化学原料和化学 } \\
\text { 制品制造业 }\end{array}$ & 33 & 44.6 \\
\hline 7 & 27 医药制造业 & 2 & 2.7 & 8 & 28化学纤维制造业 & 3 & 4.1 \\
\hline 9 & 29 橡胶和塑料制品业 & 5 & 6.8 & 10 & $\begin{array}{c}30 \text { 非金属矿物制品 } \\
\text { 业 }\end{array}$ & 3 & 4. 1 \\
\hline 11 & 33 金属制品业 & 7 & 9.5 & 12 & 34通用设备制造业 & 4 & 5.4 \\
\hline 13 & 35 专用设备制造业 & 2 & 2.7 & 14 & $\begin{array}{c}38 \text { 电气机械和器材 } \\
\text { 制造业 }\end{array}$ & 5 & 6.8 \\
\hline 15 & 46 水的生产和供应业 & 2 & 2.7 & 16 & 51 批发业 & 1 & 1.4 \\
\hline 17 & 78 公共设施管理业 & 1 & 1.4 & & & & \\
\hline \multicolumn{4}{|c|}{ 合计 } & \multicolumn{4}{|c|}{74} \\
\hline
\end{tabular}

表 3 江苏某县信息采集地块不同规模地块分布表

\begin{tabular}{|c|c|c|c|c|}
\hline 序号 & 地块规模 & 企业状态 & 数量(个) & 小计 \\
\hline 1 & 大型 & / & 0 & 0 \\
\hline 2 & \multirow{2}{*}{ 中型 } & 在产 & 5 & \multirow{2}{*}{$8(11 \%)$} \\
\hline 3 & & 关闭 & 3 & \\
\hline 4 & \multirow{2}{*}{ 小型 } & 在产 & 18 & \multirow{2}{*}{$34(47 \%)$} \\
\hline 5 & & 关闭 & 16 & \\
\hline 6 & \multirow{2}{*}{ 微型 } & 在产 & 12 & \multirow{2}{*}{$31(42 \%)$} \\
\hline 7 & & 关闭 & 19 & \\
\hline 8 & 合计 & / & 1 & 73 \\
\hline
\end{tabular}




\section{2 调查地块分布}

\section{1 总体分布情况}

根据重点行业企业信息采集风险 筛查结果, 并结合省、市级相关文件要 求, 该县共涉及 81 个重点行业企业用地 调查信息采集地块, 其中本次实际调查 地块 74 个 (包括在产企业35个、关闭企 业38个、填埋场 1 个), 核实不查地块 7 个（包括“已开发再利用”地块 3 个、“开 展过场地调查”地块 4 个)。根据现场踏 勘和定位确定了企业的分布情况, 结果 显示, 该县调查地块多数分布在河流或 地表水附近, 尤其是成立时间较早的化 工企业。

\section{2 行业及规模分布特点}

\section{(1) 关注度划分}

本次空间信息整合地块共 81 个, 其 中涉及到信息采集地块 74 个。根据风险 篮查结果, 该县不涉及高风险地块, 中关 注度地块 53 个, 包括在产地块 25 个、关闭 地块 28 个; 低关注度地块 20 个, 包括在产 地块 10 个、关闭地块 10 个; 1 家填埋场不 参与风险等级划分。具体详见表1。

(2) 行业划分

根据信息采集行业类别调查结果， 调查地块的行业包括食品制造业、纺织 业等, 其中26化学原料和化学制品制造 业占比最大, 为 $44.6 \%$, 其次为金属制品 业、占比 $9.5 \%$, 具体见表 2 :

(3) 企业规模

根据信息采集企业规模调查结果， 调查地块中不涉及大型规模企业, 中型 规模企业8家 (11\%), 小型规模企业34家 (47\%), 微型规模企业31家 (42\%)。

在产企业中, 中型规模企业 5 家 (14\%)、小型规模企业18家 (52\%)、微型规 模企业 12 家 (34\%) ; 关闭企业中, 中型规模 企业3 家 $(8 \%)$ 、小型规模企业16家 $(42 \%) 、$ 微型规模企业 19 家 (50\%), 具体见表3:

\section{3 地块中重点目标分布特点}

根据风险篮查与风险分级技术规 定, 企业地块中的重点可能被污染的区 域, 主要类型有 5 类, 分别为生产车间, 储罐、产品及原辅材料储存区, 废水治 理区, 固体废物它存或处置场以及其他 污染区域。

表 4 该县地块中重点目标分类数量统计

\begin{tabular}{|c|c|c|c|}
\hline 序号 & 重点目标类型 & 数量 $($ 个) & 占比 $(\%)$ \\
\hline 1 & 11 生产车间 & 71 & 31 \\
\hline 2 & 12 储罐、产品及原辅材料储存区 & 63 & 28 \\
\hline 3 & 13 废水治理区 & 39 & 17 \\
\hline 4 & 14 固体废物近存或处置场 & 56 & 24 \\
\hline 5 & 合计 & 229 & 100 \\
\hline
\end{tabular}

表5 该县敏感受体分类地块数量统计

\begin{tabular}{|c|c|c|c|}
\hline 序号 & 敏感受体类型 & 数量 $($ 个 $)$ & 占比 $(\%)$ \\
\hline 1 & 21 学校 & 28 & 9.6 \\
\hline 2 & 22 医院 & 25 & 8.6 \\
\hline 3 & 23 居民区 & 74 & 25.4 \\
\hline 4 & 24 幼儿园 & 18 & 6.2 \\
\hline 5 & 27 食用农产品产地 & 72 & 24.7 \\
\hline 6 & 29 地表水体 & 74 & 25.4 \\
\hline 7 & 合计 & 291 & 100 \\
\hline
\end{tabular}

表 6 在产企业地块分布发展图

\begin{tabular}{|c|c|c|c|}
\hline 序号 & 成立时间 & 数量 & 占比 $(\%)$ \\
\hline 1 & 2000 年之前 & 11 & 31.4 \\
\hline 2 & $2000-2010$ 年之间 & 18 & 51.4 \\
\hline 3 & $2011-2018$ 年之间 & 6 & 17.1 \\
\hline 4 & 合计 & 35 & 100 \\
\hline
\end{tabular}

表 7 关闭企业运营时间分布发展情况

\begin{tabular}{|c|c|c|c|}
\hline 序号 & 运营时间 & 数量 & 占比 $(\%)$ \\
\hline 1 & $<5$ 年 & 4 & 10.5 \\
\hline 2 & $5-10$ 年 & 14 & 36.8 \\
\hline 3 & $10-20$ 年 & 17 & 44.7 \\
\hline 4 & $>20$ 年 & 3 & 7.9 \\
\hline 合计 & $/$ & 38 & 100 \\
\hline
\end{tabular}

表 8 关闭企业运营起始年份分布发展情况

\begin{tabular}{|c|c|c|c|}
\hline 序号 & 运营起始年份 & 数量 & 占比 $(\%)$ \\
\hline 1 & 2000 年之前 & 20 & 10.5 \\
\hline 2 & $2000-2010$ 年之间 & 17 & 36.8 \\
\hline 3 & $2011-2018$ 年之间 & 1 & 44.7 \\
\hline 4 & 合计 & 38 & 100 \\
\hline
\end{tabular}

统计该县所有地块内重点目标的数 量, 总计为 229 , 涉及到 4 类重要区域 (见 表4）。其中为生产车间类的数量最多, 为 71 , 占比 $31.0 \%$; 废水治理区类的数量 最少, 占比 $17.0 \%$ 。

\section{4 地块周围敏感受体分布特点} 分析

根据调查结果, 该县信息采集地块 周边 $1 \mathrm{~km}$ 范围内存在的敏感受体主要类 型有 6 类, 为学校、医院、居民区、幼儿
园、食用农产品产地、地表水体, 不涉及 集中式饮用水水源地、饮用水井、自然 保护区。

该县区域地块周边 $1 \mathrm{~km}$ 范围内敏感 体数量, 总计为 291 , 涉及到 6 类敏感体。 其中居民区和地表水体类数量最多, 均 为 74 , 均比 $25.4 \%$; 其次为食用农产品产 地类, 为 72 , 占比 $24.7 \%$; 医院类数量最 少, 为 25 , 占比 $8.6 \%$ 。各类敏感受体占比 见表5: 


\section{5 地块分布发展特点}

(1) 在产企业

根据本次调查数据统计, 共涉及到 在产企业地块 35 个, 其中成立时间最早 的企业为某纤维材料公司地块 (1978年), 最晚成立时间为某皮革公司地块 (2015 年)。其中 2000 年之前成立的企业地块有 11个, 2000-2010年之间的企业地块有 18 个, 2011-2018年之间的企业地块数有 6 个。具体的分布情况如表6所示:

由上表可见, 本次调查涉及的在产 企业成立时间主要集中于2000-2010年。

(2) 关闭企业

根据本次调查数据统计, 共涉及到 关闭企业地块 38 个, 其中成立时间最早 的企业为某化工公司 (1977年), 最晚的 企业为某电镀加工点 (2016年)。其中经 营时间最短的时间为某电镀加工点 (经 营1年), 最长的时间为某化工公司 (经营 32 年)。

本次调查的企业地块中, 经营时间 小于 5 年的企业地块数量有 4 个, 经营时 间5-10年的企业地块数量有 14 个, 经营
时间 10-20年的企业地块数量有 17 个, 超过 20 年的企业地块数量有 3 个。具体 见表7:

本次调查的关闭企业地块中, 成立 时间为 2000 年之前的企业地块数量为 20 个, 2000-2010年成立的企业为 17 个, 2010 年之后成立的企业数量为 1 个。 具体详见表8所示:

\section{6 结语}

根据调查结果, 江苏某县重点行业 企业用地土壤污染状况调查地块总数为 81 个, 核实不查企业地块数为 10 个, 其余 74 家企业地块中, 共涉及35家在产企业 地块, 38家关闭企业地块和1家生活垃圾 填埋场。根据调查和分析结果最终得出 以下结论:

(1) 本次调查中的大部分地块集中 于河流附近, 周边分布着居民区和地表 水体等敏感目标, 即该县工业起源于人 力资源丰富、水运交通发达区域。

(2) 本次调查中该县不涉及高风险 地块, 相比其他化工集中区, 该县地块安 全风险隐患较低。
(3) 该县调查地块中 26 化学原料和 化学制品制造业占比最大, 重点目标包 括生产车间、储罐、产品及原辅材料储 存区、废水治理区、固体废物它存或处 置场。目前随着江苏省化工行业专项整 治的进一步开展, 可进一步促进化工行 业健康稳步有序发展。

(4) 该县调查地块中主要为小型和 微型规模企业, 在产企业成立时间主要 集中于2000-2010年, 关闭企业成立时间 主要集中于 2010 年前、大部分运营时间 为5-20年, 与早年小型粗放型生产有较 大关系。

\section{[参考文献]}

[1]方建新,王璞.我国土壤污染现状 分析及防治对策研究 [J]. 资源节约与环 保,2019,(8):79.

[2]王文斌,王文志.我国土壤污染问 题的现状与思考 [J]. 农机使用与维 修,2013,(9):4-6.

[3]郭修平,郭庆海. “土十条”与上壤 污染治理[J].生态经济,2016,32(2):10-13. 